\title{
Safety of esophagogastroduodenoscopy- guided forceps biopsy and the feasibility of esophagogastroduodenoscopy for evaluation of hypopharyngeal cancer
}

Hyun Jun Hong ${ }^{2}$, Seok-Hoo Jeong ${ }^{1}$, Won Shik $\mathrm{Kim}^{3}$ and Yu Jin Kim ${ }^{1,4,5^{*}}$ [D

\begin{abstract}
Background: There is currently no established standard tissue sampling method for hypopharyngeal cancer. The present study aimed to evaluate the feasibility of esophagogastroduodenoscopy (EGD) for the pretreatment evaluation of hypopharyngeal cancer and the safety of EGD-guided forceps biopsy.

Methods: We reviewed nine patients with hypopharyngeal cancer who underwent EGD for the evaluation of tumor extent and tissue biopsy from March 2014 to March 2017 at International St. Mary's Hospital. One experienced endoscopist performed all the EGD procedures in the presence of a head and neck surgeon. The procedure included determining tumor location, extent (presence of pyriform sinus apex involvement), and size, and passing the endoscope through the upper esophageal sphincter. The success rate of tissue sampling was assessed, and procedure-related complications were recorded.

Results: All patients were male, with a mean age of 69.9 \pm 10.9 years (range 61-69 years). Tissue sampling using biopsy forceps was performed in 6/9 patients (66.7\%). No complications related to moderate sedation or biopsy, including post-biopsy bleeding or respiratory distress, were reported. Histologic confirmation was successful in 5/6 patients (83.3\%). Upper gastrointestinal lesions were evaluated in 7/9 (77.8\%) patients in whom the scope passed through the lesion.
\end{abstract}

Conclusions: EGD and EGD-guided forceps biopsy may be useful for the evaluation of hypopharyngeal cancer extent and tissue sampling, respectively.

Keywords: Esophagogastroduodenoscopy, Forceps biopsy, Hypopharyngeal cancer

\section{Background}

Hypopharyngeal cancer accounts for approximately 5\% of all head and neck cancers [1,2]. Anatomically, the hypopharynx extends from the plane of the hyoid bone above to the plane of the inferior border of the cricoid cartilage below. Hypopharyngeal cancer usually does not cause symptoms until late in the disease course [3] and

\footnotetext{
* Correspondence: kimyj@hallym.or.kr

'Department of Gastroenterology, International St. Mary's Hospital, Catholic Kwandong Universtiy College of Medicine, Incheon, South Korea

${ }^{4}$ Division of Gastroenterology, Department of Internal Medicine, Kangnam Sacred-Heart Hospital, Hallym University Medical Center, Hallym University College of Medicine, Chuncheon, South Korea

Full list of author information is available at the end of the article
}

has a higher incidence of early metastasis and poorer prognosis than laryngeal cancer [4].

Hypopharyngeal cancer is relatively uncommon and anatomically complex. Various treatment options have been used based on its stage [5]. The results of radiotherapy alone are comparable to those of partial surgery for early hypopharyngeal cancer [6]. Surgical resection, followed by radiotherapy, if necessary, reportedly results in a better survival rate in patients with advanced cancers $[7,8]$. However, the potential consequences of a radical surgical approach include significant alterations in voice and swallowing function, or complete loss of one or both. Complications such as fistulas and stenosis are common, and patients may require further surgery if

(c) The Author(s). 2019 Open Access This article is distributed under the terms of the Creative Commons Attribution 4.0 International License (http://creativecommons.org/licenses/by/4.0/), which permits unrestricted use, distribution, and reproduction in any medium, provided you give appropriate credit to the original author(s) and the source, provide a link to the Creative Commons license, and indicate if changes were made. The Creative Commons Public Domain Dedication waiver (http://creativecommons.org/publicdomain/zero/1.0/) applies to the data made available in this article, unless otherwise stated. 
they survive [5]. Therefore, it is important to select the best treatment option.

Pretreatment diagnosis includes histologic confirmation and staging. Although squamous cell carcinoma comprises more than $90 \%$ of cancers of the hypopharynx [9], histological confirmation of the tumor is essential. Direct visualization of the lesion using a rigid laryngoscope under general anesthesia and tissue sampling is currently the standard diagnostic method. Patients with hypopharyngeal cancer are usually of old age and present with medical comorbidities. Therefore, a surgical procedure under general anesthesia is a burden for both the patient and the surgeon.

Upper gastrointestinal endoscopes have some advantages over rigid or flexible laryngoscopes, as they have better resolution and flexibility and can detect concomitant esophageal squamous dysplasia or carcinoma. Wang et al. [10] described the evaluation of upper gastrointestinal non-neoplastic lesions using an ultrathin endoscope. Due to the risk of bleeding and airway obstruction, however, tissue sampling using a gastroscope is not the procedure of choice. As of yet, no standard diagnostic test has been established. The present study aimed to evaluate the feasibility of gastroscopy for the evaluation of tumor extent, and the safety of tissue sampling using a gastroscope.

\section{Methods}

\section{Patients}

The medical records of consecutive primary hypopharyngeal cancer patients who underwent esophagogastroduodenoscopy (EGD) from March 2014 to March 2017 at International St. Mary's Hospital were retrospectively reviewed. Hypopharyngeal tumors were detected via neck computed tomography (CT), magnetic resonance imaging (MRI), and/or laryngoscopy before EGD. All study protocols were retrospectively approved by our institutional review board (submission number IS17RASI0065).

\section{EGD and tissue sampling}

One endoscopist (Kim YJ) performed all EGD procedures in the presence of one head and neck surgeon (Hong HJ). A single-channel gastroscope (GIF-Q260), Olympus, Tokyo, Japan) or an ultrathin endoscope (GIF-XP260N, Olympus, Tokyo, Japan) was used with or without sedation. Tissue sampling was performed using disposable biopsy forceps (FB-230 K, Olympus, Tokyo, Japan). Inspection, photography, and narrow-band imaging of hypopharyngeal lesions were performed both before and after passage through the pyriform sinus. During EGD, primary tumor extent, scope passage through the pyriform sinus, number of tissue samples taken using biopsy forceps, and the presence or absence of concomitant esophageal and gastric lesions were recorded. After EGD, we also assessed the accuracy of diagnosis based on EGD-guided biopsy histology and post-procedure complications, including post-biopsy hemorrhage or perforation. The accuracy of pathologic diagnosis using EGD guided forceps biopsy and passage of the endoscope through the tumor were evaluated.

\section{Results}

Table 1 shows the demographic data and clinical staging of the nine patients. All patients were male, with a mean age of $69.9 \pm 10.9$ years (range 61-69 years). Five patients underwent concurrent chemoradiation therapy, and the other four were administered best palliative care.

Tumors were located in the pyriform sinus, post-cricoid area, and posterior pharyngeal wall (Fig. 1). The lesions were located in the pyriform sinus in $5 / 9$ patients (Table 2 ). Endoscopy was observed in real time by one ear, nose, and throat specialist (Hong HJ) (Additional file 1: Video S1), who assessed tumor location and extent, as well as the involvement of the pyriform sinus inlet.

EGD was performed with sedation in six patients and without sedation in three. The sedatives used were midazolam $(0.07-0.15 \mathrm{mg} / \mathrm{kg}$, intravenous) and pethidine (25-50 mg, intravenous). In two patients, the endoscope

Table 1 Demographic data and clinical stages of the enrolled patients

\begin{tabular}{|c|c|c|c|c|}
\hline Patient number & Sex & Age range (years) & Stage & Treatment \\
\hline 00298963 & male & $65-70$ & cT2NOMO, & CCRT \\
\hline 00298607 & male & $60-65$ & cT4aNOMx & cT4aNOMx \\
\hline 00272563 & male & $60-65$ & cT4aN2cMx & CCRT \\
\hline 00164374 & male & $75-80$ & cT4aN1Mx & CCRT \\
\hline 00294335 & male & $85-90$ & cT4bN2cMx & best supportive care \\
\hline 00252398 & male & $50-55$ & $\mathrm{cT} 2 \mathrm{~N} 2 \mathrm{bMx}$ & CCRT \\
\hline 00247856 & male & $80-85$ & cT4bN2bMx & best supportive care \\
\hline 00225664 & male & $60-65$ & - & best supportive care \\
\hline 00176506 & male & $75-80$ & cT4aN2cMx & best supportive care \\
\hline
\end{tabular}



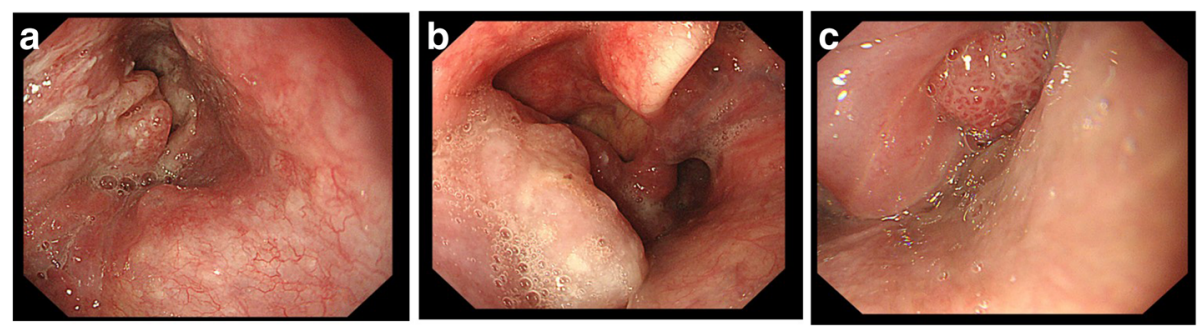

Fig. 1 Hypopharyngeal cancers at different locations. a Pyriform sinus, b posterior pharyngeal wall, c post-cricoid area

could not pass through the hypopharyngeal mass. In one patient, only an ultrathin endoscope could pass through the mass. Biopsy using forceps was performed in $6 / 9$ patients (66.7\%) (Fig. 2). In 3/9 patients, the role of EGD was confined to the evaluation of tumor extent. The success rate of forceps biopsy was $83.3 \%$ (5/6 patients). The number of tissue fragments ranged from two to four. The success of forceps biopsy was not significantly associated with the number of tissue fragments, location of the lesion, or use of sedation.

Procedures were performed on hospitalized patients. No complications related to moderate sedation or biopsy, including respiratory distress or post-biopsy bleeding, were reported. Concomitant upper gastrointestinal lesions included esophageal candidiasis, intestinal metaplasia, peptic ulcer scar, and duodenal polyp. No synchronous cancers were detected.

\section{Discussion}

In the United States and Canada, $65-85 \%$ of hypopharyngeal carcinomas involve the pyriform sinuses, $10-20 \%$ involve the posterior pharyngeal wall, and 5-15\% involve the post-cricoid area [11]. Due to its anatomical complexity, no standard treatment for cancer of the hypopharynx has been established. Expert guidelines recommend surgical resection for T1 cancer [12]. Expert guidelines recommend biopsy of the primary site or fine-needle aspiration of the neck, chest CT, CT with contrast, and/or MRI with contrast of the primary site and neck, and endoscopy under anesthesia for pretreatment evaluation [12]. To select surgical candidates, tumor extent should be evaluated. Rigid laryngoscopy under general anesthesia is usually the diagnostic method of choice.

Developments in endoscopy have made minimally invasive treatment possible in diseases of various organs.

Table 2 Results of esophagogastroduodenoscopy in the enrolled patients

\begin{tabular}{|c|c|c|c|c|c|c|c|c|c|}
\hline $\begin{array}{l}\text { Patient } \\
\text { number }\end{array}$ & Sex & $\begin{array}{l}\text { Age } \\
\text { range } \\
\text { (years) }\end{array}$ & Sedation & Location & $\begin{array}{l}\text { Histologic } \\
\text { diagnosis using } \\
\text { EGD forceps }\end{array}$ & Complication & $\begin{array}{l}\text { Passage } \\
\text { of scope }\end{array}$ & $\begin{array}{l}\text { Number of } \\
\text { biopsied tissue } \\
\text { fragments }\end{array}$ & $\begin{array}{l}\text { Concomitant upper } \\
\text { gastrointestinal disease }\end{array}$ \\
\hline 00298963 & male & $65-70$ & + & $\begin{array}{l}\text { posterior pharyngeal } \\
\text { wall and pyriform sinus }\end{array}$ & - & no & yes & 0 & $\begin{array}{l}\text { reflux esophagitis, gastric } \\
\text { polyp, duodenal ulcer } \\
\text { active stage }\end{array}$ \\
\hline 00298607 & male & $60-65$ & - & pyriform sinus & $\begin{array}{l}\text { squamous cell } \\
\text { carcinoma }\end{array}$ & no & yes & 4 & $\begin{array}{l}\text { atrophic gastritis, } \\
\text { intestinal metaplasia }\end{array}$ \\
\hline 00272563 & male & $60-65$ & - & pyriform sinus & $\begin{array}{l}\text { squamous cell } \\
\text { carcinoma }\end{array}$ & no & yes & 3 & duodenal polyp \\
\hline 00164374 & male & $75-80$ & + & pyriform sinus & $\begin{array}{l}\text { squamous cell } \\
\text { carcinoma }\end{array}$ & no & yes & 3 & $\begin{array}{l}\text { atrophic gastritis, } \\
\text { intestinal metaplasia }\end{array}$ \\
\hline 00294335 & male & $85-90$ & + & pyriform sinus & $\begin{array}{l}\text { a few necrotic } \\
\text { atypical squamous } \\
\text { cells }\end{array}$ & no & $n o^{a}$ & 3 & $\begin{array}{l}\text { atrophic gastritis, } \\
\text { intestinal metaplasia }\end{array}$ \\
\hline 00252398 & male & $50-55$ & + & postcricoid area & $\begin{array}{l}\text { squamous cell } \\
\text { carcinoma }\end{array}$ & no & yes & 2 & Gastric ulcer scar \\
\hline 00247856 & male & $80-85$ & + & $\begin{array}{l}\text { posterior } \\
\text { pharyngeal wall }\end{array}$ & $\begin{array}{l}\text { squamous cell } \\
\text { carcinoma }\end{array}$ & no & yes & 3 & \\
\hline 00225664 & male & $60-65$ & - & $\begin{array}{l}\text { posterior } \\
\text { pharyngeal wall }\end{array}$ & - & no & yes & 0 & esophageal candidiasis \\
\hline 00176506 & male & $75-80$ & - & $\begin{array}{l}\text { posterior pharyngeal } \\
\text { wall/postcricoid area }\end{array}$ & - & no & no & 0 & \\
\hline
\end{tabular}




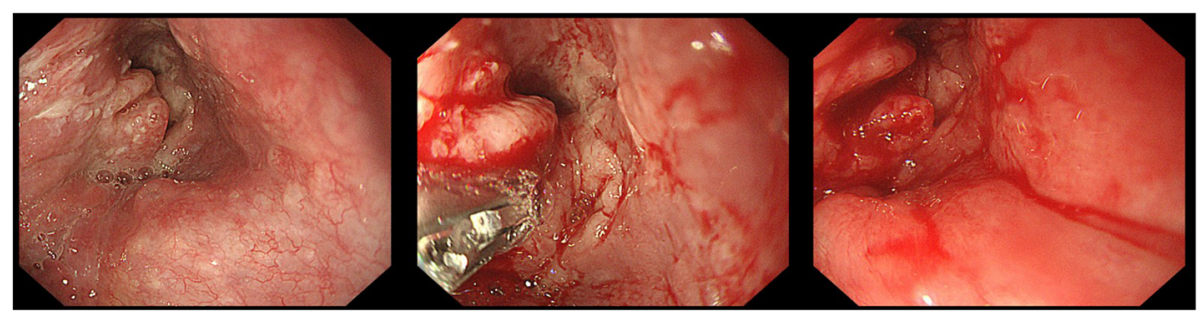

Fig. 2 Tissue sample collection using biopsy forceps

Flexible endoscopy has advantages over rigid laryngoscopy in that it is less uncomfortable for patients and does not require sedation. Gastrointestinal endoscopy yields better resolution than flexible laryngoscopy, and enables the concomitant evaluation of esophageal, gastric, and duodenal lesions.

Five studies have reported that office-based biopsy for head and neck cancers under local anesthesia using flexible digital video laryngoscopy or transnasal fiberoptic endoscopy is safe and can successfully yield a histopathological diagnosis [13-17]. Of these five studies, three included hypopharyngeal cancer patients $(n=2$ a, $n=8 \mathrm{~d}$ $n=8$ ), while the other two included only laryngeal cancer patients. Hypopharyngeal cancer extends below the pyriform sinus inlet, and sometimes lesions are not visible via laryngoscopy. Moreover, the incidence of synchronous esophageal dysplasia or carcinoma is higher in patients with hypopharyngeal cancer than in the general population, and upper gastrointestinal endoscopy is essential. Biopsy and upper gastrointestinal evaluation can be achieved using upper gastrointestinal endoscopes.

The success rate of tissue biopsy was $83.3 \%$ in the current study. In a previous study of hypopharyngeal cancer, the success rate was 100\% [13]. The reported success rates of forceps biopsy through an endoscope biopsy channel in this and previous studies are acceptable; however, the currently available reported sample sizes are small.

No complications, including post-biopsy bleeding or respiratory distress during endoscopy, were observed in the present study. Mild to moderate sedation is needed, however, due to retching.

The study had some limitations. First, it was a singlecenter retrospective study, which may limit the reach of the conclusions; second, the study had a small sample size.

\section{Conclusions}

EGD appears to be a feasible option for the pretreatment diagnosis and biopsy of hypopharyngeal cancer; our limited sample size showed that an acceptable success rate may be achieved. EGD can reduce the burden of general anesthesia and enables the concomitant evaluation of upper gastrointestinal lesions.

\section{Additional file}

Additional file 1: EGD-guided forceps biopsy for hypopharyngeal cancer. The gastroscope passed through the opposite side of the tumor to avoid bleeding. After observing the esopahgus, stomach and duodenum, the distal border of the tumor was assessed while withdrawing the scope. Tissue sampling was performed using biopsy forceps. (MP4 37513 kb)

\section{Abbreviations}

CT: Computed tomography; EGD: Esophagogastoduodenoscopy; MRI: Magnetic resonance imaging

\section{Acknowledgements}

Narration of the video clip was recorded by Na Yong Kim.

This study was presented at Asia-Pacific Digestive Week (APDW) 2018 (OE0856 (PE-0188))

\section{Authors' contributions}

$\mathrm{HHJ}$ formed the concept and collected data. KYJ performed endoscopy and interprete data. KYJ wrote the manuscript. KWS and JSH revised the manuscript. All authors read and approved the final version of this manuscript.

\section{Funding}

This study was not funded by an external source.

\section{Availability of data and materials}

The datasets used and/or analysed during the current study available from the corresponding author on reasonable request.

\section{Ethics approval and consent to participate}

This study was approved by the Institutional Review Board (IRB) of the International Saint Mary's Hospital (submission number IS17RASI0065). All procedures performed in studies involving human participants were in accordance with the ethical standards of the institutional and/or national research committee and with the 1964 Helsinki declaration and its later amendments or comparable ethical standards. Written informed consent forms about the procedure were obtained for all patients before surgery.

\section{Consent for publication}

Not applicable.

\section{Competing interests}

The authors declare that they have no competing interests.

\section{Author details}

${ }^{1}$ Department of Gastroenterology, International St. Mary's Hospital, Catholic Kwandong Universtiy College of Medicine, Incheon, South Korea.

2Department of Otorhinolaryngology, International St. Mary's Hospital, Catholic Kwandong Universtiy College of Medicine, Incheon, South Korea. ${ }^{3}$ Division of Gastroenterology, Deparment of Internal Medicine, Kangnam Sacred-Heart Hospital, Hallym University Medical Center, Hallym University College of Medicine, Seoul, South Korea. ${ }^{4}$ Division of Gastroenterology, Department of Internal Medicine, Kangnam Sacred-Heart Hospital, Hallym University Medical Center, Hallym University College of Medicine, 
Chuncheon, South Korea. ${ }^{5}$ Yonsei University College of Medicine, 1, Singil-ro, Yeongdeungpo-gu, Seoul, Republic of Korea.

Received: 10 January 2019 Accepted: 30 July 2019

Published online: 08 August 2019

\section{References}

1. Ferlay J, Soerjomataram I, Dikshit R, Eser S, Mathers C, Rebelo M, Parkin DM, Forman D, Bray F. Cancer incidence and mortality worldwide: sources, methods and major patterns in GLOBOCAN 2012. Int J Cancer. 2015;136(5):E359-86.

2. Siegel RL, Miller KD, Jemal A. Cancer statistics, 2017. CA Cancer J Clin. 2017:67(1):7-30

3. Hypopharyngeal Cancer Treatment (PDQ(R)): Health professional version. In: PDQ Cancer Information Summaries. edn. Bethesda 2002. https://www.ncbi. nlm.nih.gov/books/NBK82221/.

4. Cooper JS, Porter K, Mallin K, Hoffman HT, Weber RS, Ang KK, Gay EG, Langer CJ. National Cancer Database report on cancer of the head and neck: 10-year update. Head \& neck. 2009;31(6):748-58.

5. Bradley PJ. Cancer of the hypopharynx. Oper Tech Otolaryngol Head Neck Surg. 2005;16(1):55-66.

6. Jones $\mathrm{A}$. The management of early hypopharyngeal cancer: primary radiotherapy and salvage surgery. Clin Otolaryngol Allied Sci. 1992; 17(6):545-9.

7. Kim S, Wu HG, Heo DS, Kim KH, Sung MW, Park Cl. Advanced hypopharyngeal carcinoma treatment results according to treatment modalities. Head Neck. 2001;23(9):713-7.

8. Cheng CT, Lin CY, Hung-Chun Cheng S, Lin YP, Lim LC, Pennarun N, Liu ZY, Terng SD. Survival benefit of surgical approach for advanced oropharyngeal and hypopharyngeal cancer: a retrospective analysis. Head Neck. 2017; 39(10):2104-13.

9. Sanderson RJ, Ironside JA. Squamous cell carcinomas of the head and neck. BMJ. 2002;325(7368):822-7.

10. Su YY, Chen WC Fau-Chuang H-C, Chuang HC, Fau-Guo C-S, Guo CS Fau-Lin Y-T, Lin YT Fau-Luo S-D, Luo SD Fau-Fang F-M, Fang FM Fau-Chien C-Y, Chien CY. Effect of routine esophageal screening in patients with head and neck cancer. JAMA Otolaryngology-Head and Neck Surgery. 2013;139(4): $350-54$

11. Pignon JP, Bourhis J, Domenge C, Designe L. Chemotherapy added to locoregional treatment for head and neck squamous-cell carcinoma: three meta-analyses of updated individual data. MACH-NC Collaborative Group. Meta-Analysis of Chemotherapy on Head and Neck Cancer. Lancet (London, England). 2000;355(9208):949-55.

12. Adelstein D, Gillison ML, Pfister DG, Spencer S, Adkins D, Brizel DM, Burtness B, Busse PM, Caudell JJ, Cmelak AJ. NCCN guidelines insights: head and neck cancers, version 2.2017. J Natl Compr Cancer Netw. 2017:15(6):761-70.

13. Schutte HW, Takes RP, Slootweg PJ, Arts MJPA, Honings J, van den Hoogen FJA, Marres HAM, van den Broek GB. Digital video laryngoscopy and flexible endoscopic biopsies as an alternative diagnostic workup in laryngopharyngeal Cancer: a prospective clinical study. Ann Otol Rhinol Laryngol. 2018;127(11):770-6.

14. Cohen J, Benyamini L. Transnasal flexible Fiberoptic in-office laryngeal biopsies-our experience with 117 patients with suspicious lesions. Rambam Maimonides Med J. 2014;5(2):e0011.

15. Naidu H, Noordzij JP, Samim A, Jalisi S, Grillone G. Comparison of efficacy, safety, and cost-effectiveness of in-office cup forcep biopsies versus operating room biopsies for laryngopharyngeal tumors. J Voice. 2012;26(5):604-6.

16. Cha W, Yoon B-W, Jang J, Lee J, Lee B, Wang S-G, Cho J, Cho I. Office-based biopsies for laryngeal lesions: analysis of consecutive 581 cases. Laryngoscope. 2016:126(11):2513-9.

17. Lippert D, Hoffman M, Dang P, McCulloch T, Hartig G, Dailey S. In-office biopsy of upper airway lesions: safety, tolerance, andEffect on time to treatment. Laryngoscope. 2015;125(4):919-23.

\section{Publisher's Note}

Springer Nature remains neutral with regard to jurisdictional claims in published maps and institutional affiliations.

Ready to submit your research? Choose BMC and benefit from:

- fast, convenient online submission

- thorough peer review by experienced researchers in your field

- rapid publication on acceptance

- support for research data, including large and complex data types

- gold Open Access which fosters wider collaboration and increased citations

- maximum visibility for your research: over $100 \mathrm{M}$ website views per year

At $\mathrm{BMC}$, research is always in progress.

Learn more biomedcentral.com/submissions 